\title{
Thiamethoxam in Papaya (Carica papaya Linnaeus) Agroecosystems
}

\author{
Megchún-García Juan Valente ${ }^{1}$, Rodríguez-Lagunes Daniel Arturo ${ }^{1}$, Castañeda-Chávez María del Refugio ${ }^{2 *}$ Murguía- \\ González Joaquín ${ }^{1}$, Lango-Reynoso Fabiola ${ }^{2 *}$, Leyva-Ovalle Otto Raúl ${ }^{1,}$.
}

\begin{abstract}
${ }^{1}$ Universidad Veracruzana Campus Córdoba; Faculty of Biological and Agricultural Sciences, Región Orizaba-Córdoba. Camino Peñuela-Amatlán s/n Peñuela, Municipio de Amatlán de los Reyes, Veracruz. México. C. P. 94945 . Teléfonos: +52 $2717166410 ;+522717166129$ ext. 3751.

${ }^{2}$ Tecnologico Nacional de México/Instituto Tecnológico de Boca del Río. Km 12 carretera Veracruz-Córdoba, Boca del Río, Veracruz. México. C.P. 94290. Tel (01 229) 6905010.
\end{abstract}

\begin{abstract}
Papaya (Carica papaya L.) is a profitable fruit of economic and food importance in Mexico and Central America. Veracruz is the state in Mexico with the highest cultivable area, eventhough its production presents numerous phytosanitary problems, which are being faced with the use of the pesticide thiamethoxam. The aim of this study was to make a diagnosis of the use and management of thiamethoxam in papaya agroecosystems in the municipality of Cotaxtla, Veracruz. Two surveys were applied, one to a $30 \%$ of the total number of producers organized by an association dedicated to papaya culture, and the other survey was through key informants, both surveys were designed using the snowball sampling, a non-probability sampling technique. The results indicate that $6 \%$ of papaya producers use mainly the pesticide thiamethoxam, which belongs to the chemical group of neonicotinoids. It was found out that for five years there have been records of thiamethoxam use in vertisoils. During the cycle of papaya cultivation the producers use a maximum dose of $3 \mathrm{~L} / \mathrm{ha}$ and a minimum dose of $250 \mathrm{ml} / \mathrm{ha}$ per crop cycle. One hundred per cent of those who apply thiamethoxam are not aware of its use and efficient management, nor of the damage they are doing or have caused to agroecosystems.
\end{abstract}

Keywords- Thiamethoxam, Carica papaya L., neonicotinoids.

\section{INTRODUCTION}

Tropical agroecosystems are ecological systems modified by man that have the job of generating a good or service, and are obtained from the processes of agricultural production, with the purpose of satisfying the needs of the population, such as economic, moral, social or spiritual type [22]. Carica papaya L. agroecosystem, is a dynamic production system integrated by short cycle crops that allow having an income several times a year, unfortunately affected by the economic loss that is generated by the pests and diseases that occur in the crops. Papaya is a profitable fruit tree in Mexico and Central America, its cultivation is carried out with a minimum investment of one hundred thousand Mexican pesos per hectare [25], most of this investment is focused in the acquisition of agrochemicals to combat pests and diseases. In 2015, Veracruz became the main papaya producer state with a cultivated area of $18 \%$ of the total area of papaya established in Mexico, and the municipality of Cotaxtla contributes with $19 \%$ of the total agricultural land of papaya in Veracruz [24]. Aphids are the most economically important pests in Mexico, among them the red spider (Tetranychus cinnabarinus) and the white mite (Polyphagotarsonemus latus) stand out; a characteristic of these aphids is that they damage the foliage of papaya plants. Another important pest in Mexico and in other countries like India is the mealybug (Planococcus sp.) that acts as a vector of viral diseases. Of the minor pests are the parakeet (Acanophora projecta) and the papaya fly (Toxotrypana curvicauda). For that reason cultural management in the control of pests is fundamental to obtain fruit of commercial quality. It is necessary to respond to the sustainable development policies of the General Assembly of the United Nations (UN), where the use of organic products, entomopathogenic fungi and plant barriers is recommended to minimize the damage caused by pests and at the same time maintain an ecological balance of biodiversity [14, 28]. This effort to use organic products does not respond to the demands and requirements of the agricultural sector, therefore producers use pesticides massively in papaya crops. Training is also considered necessary for proper management culture of chemical waste that is the result of pesticides used at plot level. This chemical waste is one of the major factors in soil and groundwater contamination through leaching, percolation and entrainment of chemical molecules towards the aquifer. Currently, farmers use organophosphorus products for the management of the "Maradol" papaya crop, one of the disadvantages of handling pesticides such as parathion, diazinon and malathion, is the harm caused in humans by intoxication known as cholinergic syndrome. However, 
this chemical group is not the only one that has caused damage, there are also the neonicotinoids, which are a chemical group that causes ecological damages, such as death of birds that eat tropical fruits [7, 9 and 8], mainly in the flowering stage until reaching the production one that begins three or four months after flowering [4]. The use of chemicals in pest control is of global interest due to its motility ability within plant organs, besides having the capacity to accumulate in certain specific organs [27]. Currently of the authorized agrochemicals in Mexico, the group of neonicotinoids such as imidacloprid, acetamiprid, nitenpyram, thiamethoxam, thiacloprid, clothianidim and dinotefuram [26] are highly required by producers for their effectiveness in the control of sucking insects. From this chemical group, thiamethoxam is used in the control of Spodoptera frugiperda, Bemisia tabaci, aphids and triocides, sucking insects that transmit diseases in papaya crops [5]. Thiamethoxam is a systemic neonicotinoid pesticide that is characterized by its rapid effect, active by ingestion and contact, besides being an inactivator of the nicotinic receptors of the acetylcholine of the insects nervous system, causing paralysis and then death, these pesticides are effective in controlling lepidoptera $[10,11$, 2]. Thiamethoxam can last 3 years in soil, it is soluble in water and its use in crops can cause bee hives collapsing at concentrations of 0.1 to $0.5 \mu \mathrm{g} /$ hive [15], whereby the Environmental Protection Agency (EPA) and the European Food Safety Authority (EFSA) set the maximum permissible limits in fruit trees of 0.4 and $0.05 \pi \mathrm{g} / \mathrm{L}$. In addition, the damage caused to ecology and human health is innumerable. Therefore the aim of this study was to make a diagnosis of the use and management of thiamethoxam in a papaya agroecosystem, in the municipality of Cotaxtla, Veracruz in Mexico.

\section{MATERIALS AND METHODS}

The municipality of Cotaxtla, Veracruz México is located at the geographical coordinates $18^{\circ} 44^{\prime}-18^{\circ} 59^{\prime}$ north latitude and $96^{\circ} 11^{\prime}-96^{\circ} 32^{\prime}$ longitude west at an altitude of 10 to 200 meters above the sea level and is formed by papaya producers of 216 localities (Figure 1), among the most important are La Tinaja, La Capilla, Cotaxtla, Colonia Ejidal and Mata tejón. The municipality of Cotaxtla has a population of 18,821 inhabitants.

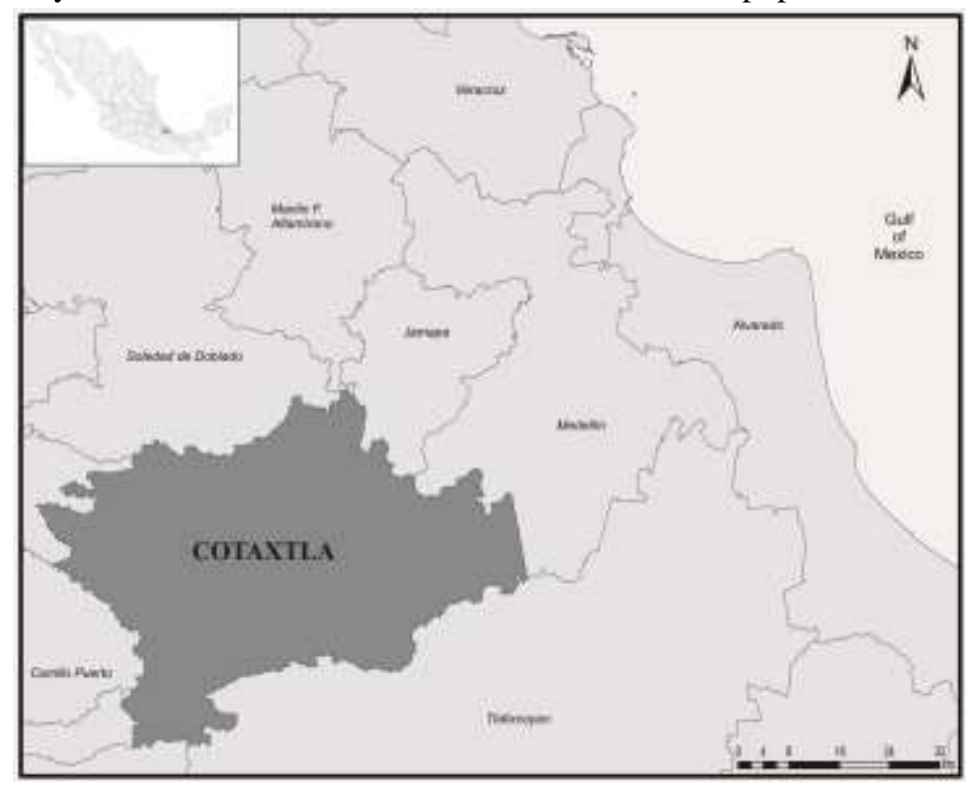

Fig.1: Location of the study area in the municipality of Cotaxtla, Veracruz México. [INEGI, 2005].

This study was carried out by means of a design and application of two surveys, one applied first to $30 \%$ of the total of papaya producers of the localities of Las Lomitas, Mata Espino, Mata Tambor, Loma de los Hoyos, Los Bajos del Tlachiconal and the municipal seat of Cotaxtla. This group of producers is constituted in an organized manner by an "Agricultural Grouping" which facilitated to carry out the surveys. The first survey was applied with an open-ended questionnaire in order to know: which groups of agrochemicals are currently used for the management of papaya crops; which are the main phytosanitary problems that they have during crops. And also if there is, as a consequence of these, a low yield of the crops that generates a negative impact to the agroecosystem. A second survey was conducted to determine the use and management of the systemic pesticide thiamethoxam. It was designed through the nonprobabilistic qualitative snowball sampling technique, and the interview was applied to key informants in order to obtain the following information: 1 . If they knew the chemical characteristics of the thiamethoxam. 2. Who the main leading papaya producers are. 3 . To have knowledge about thiamethoxam's distribution and sale in a papaya 
agricultural area. 4. Locate the major suppliers of thiamethoxam.

As a study strategy, the main commercial centers for agrochemicals in the municipality of Cotaxtla and Piedras Negras in the municipality of Tlalixcoyan, Veracruz, were identified; and key informants were interviewed (Figure 1). The data obtained were analyzed with the program statistica version 7, along with a nonparametric and parametric analysis of Kruskal Wallis.

\section{RESULTS AND DISCUSSION}

In this research the key informants were interviewed, of which 56\% of them used to grow papaya "Maradol". Among pests present in papaya crops, the producers mention that the main pest species that cause severe damage to papaya plantations are the red spider $44 \%$, mites $33 \%$ and aphids $11 \%$ (Table 1). For producers to learn to know main species, their classification and control, it is necessary to transfer technology on integrated management of pests and diseases. It is important to consider that the producers that are devoted to this activity are among 30 to 70 years old [16], so it is necessary to anticipate and train groups of young producers with attitude and aptitude for food production between 18 to 30 years old. And in doing so, to identify and form innovative leaders in the agricultural sector. Currently, $35 \%$ of agricultural producers are using organophosphorus pesticides in their crops, in order to achieve control of mites; $23 \%$ use those of the macrocyclic lactate chemical group; $12 \%$ use pyrethroids, and $6 \%$ use those of the chemical group neonicotinoids. Of the latter group $6 \%$ of the producers apply the pesticide thiamethoxam (Table 1). The massive use of pesticides in crops, mainly thiamethoxam due to its high solubility chemical characteristics, is causing an impact on the ecosystem. Aquatic systems by runoff are being affected, besides its use also represents a potential risk for productive activities that use water as a resource. Aquaculture is a productive activity in the Gulf of Mexico that is being negatively impacted by the presence of this pesticide in surface and groundwater. In addition, it is important to consider that the presence of these chemicals affects public health and provoke damages to the environment $[19,24]$.

Table.1: Chemical groups and active ingredients most used by producers in papaya agroecosystems and main pests that attack the crops.

\begin{tabular}{|c|c|c|c|c|c|}
\hline Chemical Groups & $\begin{array}{c}\text { Producers who } \\
\text { use it }(\%)\end{array}$ & Active Ingredient & $\begin{array}{c}\text { Producers who } \\
\text { use it }(\%)\end{array}$ & Pests & $\begin{array}{c}\text { Population } \\
(\%)\end{array}$ \\
\hline Nitroguanidines & 6 & Clotianidin & 6 & Nematodes & 6 \\
\hline Carbamates & 6 & Oxamyl & 6 & Red spider & 44 \\
\hline $\begin{array}{l}\text { Macrocyclic } \\
\text { lactone }\end{array}$ & 23 & Abamectin & 23 & Mites & 33 \\
\hline Organophosphates & 35 & Parathion & 11 & Wire worm & 6 \\
\hline Pyrethrins & 12 & Cypermethrin & 12 & Aphids & 11 \\
\hline Neonicotinoids & 6 & Dimethoate & 12 & & \\
\hline Chloronicotinyls & 6 & Methamidophos & 6 & & \\
\hline \multirow{4}{*}{$\begin{array}{l}\text { Saccharopolyspora } \\
\text { spinosa }\end{array}$} & 6 & Thiamethoxam & 6 & & \\
\hline & & Imidacloprid & 6 & & \\
\hline & & Malathion & 6 & & \\
\hline & & Spinosad & 6 & & \\
\hline
\end{tabular}

Nowadays, it has become a must the use and management of new pesticides in agriculture to combat pests and diseases in crops of commercial importance. This has favored the use of the systemic pesticide thiamethoxam, which can be persistent in soil for 90 days, in addition it degrades and percola itself settling in groundwater in which it is highly soluble (4.95 $\mathrm{X} 10^{-11}$ ha $\left.25^{\circ} \mathrm{C}\right)$. Its hydrolytic degradation is in a range of $\mathrm{pH}$ of 5 to 9 , reason why it is necessary to carry out studies of dissipation and motility in water, as well as learning how to handle and apply it in papaya crops, since producers use it due to its systemic and contact activity, that becomes suitable for an efficient control of sucking insects such as aphids [21, 13]. Producers from the study area of the municipality of Cotaxtla, have mentioned that mite has caused severe damage to papaya agroecosystems (Table 1). The main species present in papaya crops is the white mite (Polyphagotarsonemus latus), this causes reduction and deformation of young leaves, buds, flowers and fruits. It presents a symptomatology called "monkey 
hand", which is associated with the presence of the Papaya Annular Blight Virus (PRSV-P), this is due to the fact that the adoption of technology has been limited by the producer himself and the presence of hoarders generates that papaya producers look for alternatives for the control of pests. In addition, it is considered that the crop requires sufficient inputs for the integral management of papaya crops, the leading producers seek to share their tacit knowledge to other adoptive producers in order to improve their production systems [1 and 6].

The distribution of thiamethoxam is currently carried out in the town of Piedras Negras in the municipality of Tlalixcoya, Veracruz, under the trade name Engeo (Thiamethoxam + Lambda cyalotrina) and Actara 25WG (thiamethoxam) distributed in the municipality of
Cotaxtla, Veracruz, with the name Unikum (thiamethoxam), this means that there is a probability of a trend towards the use of thiamethoxam in the agricultural area of the municipality of Cotaxtla, mainly for the cultivation of papaya and main vegetables in the region (Table 2).

Rotation and association of papaya crops with watermelon cultivation and the proximity of papaya crops to farms where watermelon and tomato are planted or, where appropriate, the location with old papaya orchards has caused crops to be affected negatively by the presence of the virus. This phenomenon is associated with migration of major insect vectors to new papaya plantations [23].

Table.2: Characteristics of thiamethoxam distribution in the main papaya production areas in the center of the state of

Veracruz, México

\begin{tabular}{lcc|lcc}
\hline \multicolumn{1}{c}{ Variables } & $\begin{array}{c}\text { Municipalty } \\
\text { of } \\
\text { Tlalixcoyan }\end{array}$ & $\begin{array}{c}\text { Municipality } \\
\text { of } \\
\text { Cotaxtla }\end{array}$ & $\begin{array}{c}\text { Commercial } \\
\text { brand of } \\
\text { thiamethoxam }\end{array}$ & $\begin{array}{c}\text { Sale } \\
\text { percentage } \\
(\%)\end{array}$ & Pests controlled (\%) \\
\hline $\begin{array}{l}\text { Thiamethoxam } \\
\text { suppliers (\%) }\end{array}$ & 67 & 33 & Engeo & 60 & 36 \\
$\begin{array}{l}\text { Thiamethoxam sale } \\
\text { (L/year) }\end{array}$ & 140 & 6 & Actara & 20 & Whitefly \\
$\begin{array}{l}\text { Use of thiamethoxam } \\
\text { in crops }\end{array}$ & $\begin{array}{c}\text { Papaya, } \\
\text { vegetables, } \\
\text { sugar cane }\end{array}$ & $\begin{array}{c}\text { Papaya, lemon, } \\
\text { watermelon }\end{array}$ & Unikum & 20 & 18 \\
\hline
\end{tabular}

The survey showed that $45 \%$ of the producers are dedicated to the production of papaya and watermelon, $27 \%$ are only cultivating papaya, while the rest is focused on other types of crops (Table 3). There are records of the use of thiamethoxam for 5 years in crops with vertisol

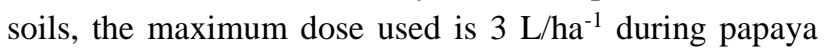
cultivation cycle on sandy loam soils (Table 4). According to studies carried out with other pesticides, thiamethoxam could become an important non-point source of groundwater contamination, due to its high soil motility [3].

Studies reported in Venezuela show that thiamethoxam applications have been made in clay-loam and clay soils, which predominate at the foot of high savannas that are vulnerable to intermittent flooding [32]. Land losses caused by conventional farming practices are considered to cause severe ecological damage, it is estimated that worldwide soil erosion is 3 million hectares and 2 million hectares are desertified on agricultural land [20], this degradation will contribute to the vulnerability of surface water and groundwater by the presence of the pesticide. Among these pesticides of the chemical group of the neonicotinoids, thiamethoxam due to its systemic characteristics and high motility, is highly effective in papaya cultivation, mainly in the combat of sucking insects that transmit diseases. Its efficacy can be observed 7 days after its application [12]. Although damage to the agroecosystem could be a high risk, it has been reported that thiamethoxam in concentrations of 1 to $100 \mathrm{ppb}$ in flowers and fruit plants causes death in bees; $10 \mathrm{ppb}$ in water causes death in aquatic species, and also $10 \mathrm{ppb}$ in agricultural layer damages macrofauna and soil microflora [31]. 
Table.3: Predominant cultures in papaya agroecosystems and its relation to thiamethoxam.

\begin{tabular}{ccc}
\hline Crops & Presence in agroecosystem (\%) & Thiamethoxam use (Years) \\
\hline Papaya-Vegetables & 9 & 4 \\
Papaya-Corn-Watermelon & 9 & 0 \\
Papaya & 27 & 2 \\
Papaya-Corn & 9 & 0 \\
Papaya-Watermelon & 45 & 2.5 \\
\hline
\end{tabular}

Table.4: Applications of thiamethoxam in different types of soil and crop cycle in the municipality of Cotaxtla Veracruz, México.

\begin{tabular}{lcc}
\hline Soil types & Application of thiamethoxam (Years) & During the growing cycle (ml/ha) \\
\hline Clay & 3.8 & 700 \\
Sandy-clay & 1.5 & 250 \\
Sandy & 0 & 0 \\
Loamy sand & 2 & 3000 \\
Vertisol & 5 & 600 \\
\hline
\end{tabular}

In the locality of Loma de los Hoyos Cotaxtla the maximum dose used in crops is $3 \mathrm{~L} / \mathrm{ha}$, unlike the producers of the locality of Lomitas who mentioned that they do not use thiamethoxam in papaya crops. The group of producers of Los Bajos de Tlachiconal used a dose lower than $500 \mathrm{ml} / \mathrm{ha}$ in the cycle of papaya cultivation, which represents a significant difference with respect to the group of producers of the locality of Mata Espino, who apply a dose of 1 1/ha (Figure 2). Currently in countries like India, in relation to the control of Paracoccus marginatus in papaya cultivation, they found out that profenophos $50 \mathrm{EC}(0.05 \%)$ and acephate $75 \mathrm{SP}$ $(0.075 \%)$, are more efficient in $90 \%$ and $80 \%$ with reference to $78 \%$ of the mortality index of the pesticide thiamethoxam, although papaya producers are using biopesticides to control this pest $[18,12]$. Thiamethoxam is efficient in the control of Empoasca fabae Harris with a protection of 31 to 38 days on the crop and of Bemisia spp. as a major vector of papaya ringspot virus, reducing the adult population to $97 \%$ after 14 days of foliar treatment [2]. In addition, it controls the pests of the coleopteran, hemiptera and lepidoctera families, mainly to Tagosodes orizicolus in a period of 21 days, these species may be responsible for the presence of papaya virus [32]. An alternative for the control of aphids in papaya cultivation is the use of reflective and black plastic mulch, these plastic covers reduce insect-pest populations and contribute to reduce the presence of virus, it is also important to consider the use of biodegradable plastics since it provides better development of plants [30; 29]. Biological control may be an alternative for tropical papaya agroecosystems that are negatively impacted by the excessive use of pesticides, although the management of neonicotinoids such as thiamethoxam has regained importance because of its nicotine-like effect by blocking acetylcholine receptors of the central nervous system of the insect. The use of organic products and live barriers such as Maize can be an alternative for the control of pests and diseases of the crop, as well as for the production of innocuous foods [10, 23].

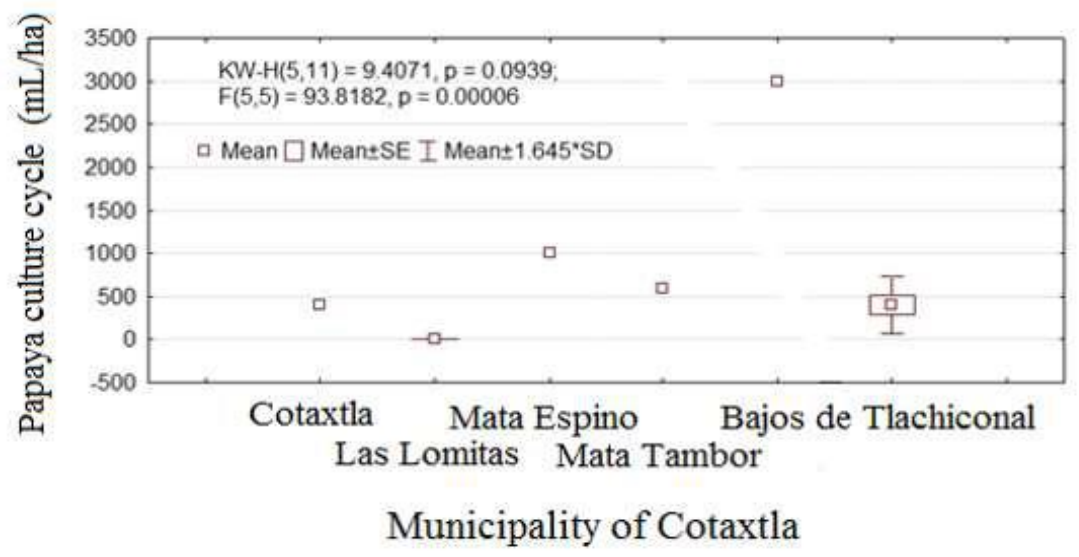

Fig.2: Thiamethoxam use in papaya culture cycle in the municipality of Cotaxtla Veracruz, México. 


\section{CONCLUSIONS}

Producers prefer ENGEO ${ }^{\circ}$ (Thiamethoxam + Lambdacyhalothrin), which is most frequently used in papaya cultivation. One hundred per cent of those applying this product are unaware of its use and efficient handling, and damage that may cause to agroecosystems. It is necessary to carry out scientific research to know the concentrations of thiamethoxam in soil, water and plant and to know if it does not exceed the permissible limits established by EPA and EFSA. Thiamethoxam tends to be used more by papaya producers because of its efficiency in combating crop pests, but it is necessary to validate the product in the field to use the effective dose in crops and it is also important to evaluate it with organic insecticides and chemical products recommended for each crop.

\section{ACKNOWLEDGEMENTS}

A special thanks to the papaya producers of the municipality of Cotaxtla Veracruz, México for their interest in supporting this research

\section{REFERENCES}

[1] Alcantará J. A., Santillán G. Ma. T., Otero C. G., Mora A. A., Gutiérrez E. M. A., Hernández C. E., 2011. Relación entre Polyphagotarsonemus latus (Acari: Tarsonemidae) y el virus de la mancha anular del papayo (PRSV-p). Revista Colombia de Entomología 37(2): 228-233.

[2] Almándoz P. J. E., Rodríguez M. F., Palacios A. J., Díaz R. J. A., 2009. Efectividad biológica del fungicida/insecticida thiamethoxam 20\% + difenoconazol 20\%+mefenoxan 2\%PS sobre insectos y enfermedades en frijol (Phaseolus vulgaris LIN). Fitosanidad 13(3): 211-217.

[3] Bedmar F., Gianelli, V., Angelini, H., Vigilianchino, L. 2005. Riesgo de contaminación del agua subterránea con plaguicidas en la cuenca del arroyo El Cardalito, Argentina. Revista de investigaciones agropecuarias. 41(1): 70-82.

[4] Bogantes A. A., Hernández C. M., Mora N. E., 2010. Herbicidas para el control de Spermacoce tenuior L. en papaya (Carica papaya L.). Agronomía Mesoamericana, 21 (1): 185-192.

[5] Campuzano M. A., Rodríguez M. C. Lagunes T. A., Llanderal C. C., Terán V. A. P., Vera G. J., Vaquera H. H., Silva A. G. 2010. Aptitud biológica de poblaciones de Bemisia tabaci (Gennadius) Biotipo B (Hemiteptera: Aleyrodidae) con diferentes susceptibilidades al Insecticida Thiametoxam. Neutropical Entomology 39(3): 430-435.

[6] Cano R. O., Villanueva J. J. A., Reta M. J. L., Huerta De la P. A., Zarazúa J. A., 2015. Investigación participativa y redes de innovación en agroeocosistemas con papayo en Cotaxtla, Veracruz, México. 2015. Investigación participativa y redes de innovación en agroecosistemas con papayo en Cotaxtla, Veracruz, México. Agricultura, Sociedad y Desarrollo, 12: 219-237.

[7] Cobos V. M., Mora M. A., y Escalona G., 2006. Inhibición de colinesterasa plasmática en el zorzal pardo (Turdus grayi), expuesto a diazinón en cultivos de papaya "Maradol" en Yucatán, México. Revista toxicol 23: 17-21.

[8] Domínguez G. D. I., Rosario C. R., Almazán G. C., Saltijeral O. J. A., y De la Fuente J., 2010. Boophilus microplus: Aspectos biológicos y moleculares de la resistencia a los acaricidas y su impacto en la salud animal. Tropical and Subtropical Agroecosystems, 12: $181-192$.

[9] Fernández A. D. G., Mancipe G. L., Fernández A. D. C., 2010. Intoxicación por organofosforados. Revista MED, 18 (1): 84-92.

[10] Filho A. B., Almeida J. E. M., Lamas C., 2001. Effect of thiamethoxam on entomopathogenic microorganisms. Neotropical Entomology 30 (3): 437-447.

[11] Fishel, 2005. Pesticide toxicity profile: Noenicotinoid pesticides. PI-80 Gainesville. Universidad de Florida/ Institute of Food and Agricultural Sciences (IFAS): 3 p. Email: http://edis.ifas.ufl.edu.

[12] Gowda G. B., Kumar L. V., Jagadish K. S., Kandakoor S. B., and Rani A. T., 2013. Efficacy of insecticides against papaya mealybug, Paracoccus marginatus Williams and de granara de Willink (Hemiptera: Pseudococcidae). Current Biotica 7(3): 161-173.

[13] Gupta S., Gajbhiye V. T., Gupta R. K., 2008. Soil dissipation and leach behavior of a neonicotinoid insecticide thiamethoxam. Bull Environ Toxicol, 80: 431-437: Doi 10.1007/s00128-008-9420-y

[14] Guzmán R. E., Gómez A. R., Pohlan H. A. J., Álvarez R. J. C., Pat F. J. H., Geissen V. 2008. La producción de papaya en Tabasco y los retos del desarrollo sustentable. El cotidiano (23) 147: 99-106.

[15] Hassani A. K., Dacher M., Gary V., Lambi M., Gauthier M., Armengaud, 2008. Effects of sublethal doses of acetamiprid and thiamethoxam on the behavior of the honeybee (Apis mellifera). Arch Environ Contam Toxicol 54: 653-661.

[16] Hernández C. E., Martínez D. J. P., Gallardo L. F., Villanueva J. J. A., 2008. Aceptación de nueva tecnología por productores ejidales para el manejo integrado del cultivo de papayo. Tropical and Subtropical Agroeosystems, 8 (2008): 279-288. 
[17] INEGI. 2005. II Conteo de población y vivienda. Prontuario de información geográfica municipal de Cotaxtla, Veracruz.

[18] Janaki I., Suresh S. and Karuppuchamy P., 2012. Efficacy and economics of biopesticides for the management of papaya mealybug, Paraccocus marginatus (Williams and Granara de Willink) in brinjal (Solanum melongena L.). J Biopest. 5(1): 8790.

[19] Lango R. F., Castañeda C. Ma del R., Landeros S. C., Galaviz V. I., Navarrete R. G. y Soto E. A., 2013. $\mathrm{Cd}, \mathrm{Cu}, \mathrm{Hg}$ and $\mathrm{Pb}$, and organochlorines pesticides in commercially important benthic organisms coastal lagoons SW Gulf of México. Agriculture Science, vol 1(1): 63-79.

[20] Lugo-Morin D. R., Rey J. C., 2009. Evaluación de la vulnerabilidad a la degradación agroambiental a través del uso del sistema microleis en los suelos de los llanos centrales de Venezuela. Revista Internacional de Contaminación Ambiental. 25 (1): 43-60.

[21] Maienfisch, P. 2006. Synthesis and properties of thiamethoxam and related compounds. $\mathrm{Z}$. Naturforsch 61b: 353-359.

[22] Martínez C. C. J., Ríos C. M., Castillo L. M., Jiménez C. J. C., Cotera R. J., 2015. Sustentabilidad de agroecosistemas en regiones tropicales de México. Tropical and Subtropical Agroecosystems. 18: 113120.

[23] Megchún G. J. V., Castañeda C. Ma. del R., Rodríguez L. D. A., Murguía G. J., Lango R. F., Leyva O. O. R., 2016. Thiamethoxam in tropical agroecosystems. Global Journal of Biology, Agriculture \& Health Sciences. 5 (3): 75-81.

[24] Megchún G. J. V., Landeros S. C., Soto E. A., Castañeda C. Ma. del R., Martínez D. J. P., Nikolskii G. I., Galaviz V. I., Lango R. F., 2015. Total coliforms and Escherichia coli in surface water from a sugarcane agroecosystem in Veracruz, México. Journal of Agricultural Science, vol 7(6): 110-119. Doi: 10.5539/jas.v7n6p110.

[25] Mirafuentes H. F. y Azpeitia M. A. 2008. Azteca, primer híbrido de papaya para el trópico de México. Revista Fitotecnia Mexicana 31 (3): 291-293.

[26] Nauen R., Ebbinghaus-Kintscher U., Salgado V. L. and Kaussmann M., 2003. Thiamethoxam is a neonicotinoid precursor converted to clothianidin in insects and plants. Pesticide Biochemistry and Physiology 76 (2003): 55-69.

[27] Pérez Ma. A., Navarro H. y Miranda E., 2013. Residuos de plaguicidas en hortalizas: problemática y riesgo en México. Revista Internacional de Contaminación y Ambiente 29: 45-64.
[28] Pérez V. A., Landeros S. C., 2009. Agricultura y deterioro ambiental. Elementos 73: 19-25.

[29] Rebolledo M. A., Del Angel P. A., Megchún G. J. V., Adame G. J., Nataren V. J., Capetillo B. A., 2011. Coberteras vivas para el manejo de malezas en mango (Mangifera indica L.) cv. Manila. Tropical and subtropical agroecosystems. 13: 327-338.

[30] Robles W., Pantoja A., Abreu E., Peña J., Ortiz J., Lugo M. de L., Cortés M., Macchiavelli R., 2006. El efecto de prácticas agronómicas sobre el nivel poblacional de áfidos y virosis en Carica papaya L., Manejo Integrado de Plagas y Agroecología (Costa Rica). 77: 38-43.

[31] Van der sluijs, J. P., Amaral-rogers, V., Belzunces, L. P., Bijleveld Van Lexmond, M. F. J., Bonmatin, J. M., Chagnon, M., et al. 2015. Conclusions of the worldwide integrated assessment on the risks of neonicotinoids and fipronil to biodiversity and ecosystem functioning. Springer, environmental science and pollution research, 22: 148-154.

[32] Vivas L. E., Astudillo D., Campos L., 2009. Evaluación del insecticida thiamethoxam $25 \%$ para el manejo del insecto sogata en el cultivo de arroz en calabozo, estado Guárico, Venezuela. Agronomía Tropical 59 (1):89-98. 